\title{
Primary colorectal small cell carcinoma: A clinicopathological and immunohistochemical study of 10 cases Dina El Demellawy ${ }^{1}$, Mahmoud A Khalifa*2, Nadia Ismiil2, Shun Wong ${ }^{3}$ and Zeina Ghorab²
}

Address: ${ }^{1}$ Department of Pathology, Thunder Bay Regional Health Sciences Center, 1874 Oliver Road, Thunder Bay, Ontario P7G 1P1, Canada, 2Department of Pathology, Sunnybrook Health Sciences Center, 2075 Bayview Avenue, Toronto, Ontario M4N 3M5, Canada and ${ }^{3}$ Department of Radiation Oncology, Sunnybrook Health Sciences Center, 2075 Bayview Avenue, Toronto, Ontario M4N 3M5, Canada

Email: Dina El Demellawy - dina_eldemellawy@rogers.com; Mahmoud A Khalifa* - mahmoud.khalifa@sunnybrook.ca; Nadia Ismiil - nadia.ismiil@sunnybrook.ca; Shun Wong - shun.wong@sunnybrook.ca; Zeina Ghorab - zeina.ghorab@sunnybrook.ca

* Corresponding author

Published: 5 September 2007

Diagnostic Pathology 2007, 2:35 doi:10.1 186/1746-1596-2-35
Received: 9 July 2007

Accepted: 5 September 2007

This article is available from: http://www.diagnosticpathology.org/content/2/l/35

(c) 2007 El Demellawy et al; licensee BioMed Central Ltd.

This is an Open Access article distributed under the terms of the Creative Commons Attribution License (http://creativecommons.org/licenses/by/2.0), which permits unrestricted use, distribution, and reproduction in any medium, provided the original work is properly cited.

\begin{abstract}
Colorectal small cell carcinoma ( $\mathrm{SmCC})$ is a rare tumor with an aggressive course. The aim of this study is to summarize our experience with this tumor and to highlight its immunohistochemical profile. Ten cases of colorectal SmCC were identified in our files and a panel of immunostains was performed. Follow up was available for the average of 3 years, during which 7 patients died and 3 were alive with disease. All cases were positive for LMWK, CK 19 and pancytokeratin but were negative for TTF-I and CA 125. EGFR was positive in 7 cases. TTF-I negative staining may be valuable in differentiating it from its pulmonary counterpart. CDX2, mCEA, CD56, synaptophysin, NSE and chromogranin can help differentiate it from non-endocrine poorly differentiated adenocarcinoma. The expression of EGFR in a subset of patients has not been reported earlier and has to be evaluated in larger series to assess its role in the planning of targeted biologic therapy.
\end{abstract}

\section{Background}

Primary extra-pulmonary small cell carcinoma (SmCC) is a rare tumor encountered in several organ systems. In the digestive system, neuroendocrine carcinomas comprise less than $1 \%$ of all colorectal cancer and are classically associated with poor outcome [1]. In the few reports of colorectal SmCC (CRSmCC) in the English literature, these tumors show a similar demographic characteristics to colorectal adenocarcinomas with the exception of being more common in females. Because of the difference in prognosis and management between the two tumor types, the distinguishing histological and immunophenotypic features need to be well characterized. The aim of this study is to describe a single institution's experience with this rare tumor, focusing on its immunohistochemical features and possible utilization.

\section{Materials and methods}

This study was approved by the Institutional Research Ethics Board. Since a relatively new laboratory information system was installed in 1999, we were able to search the Anatomic Pathology database and the electronic patients' charts, between 1999 and 2006 for CRSmCC in Sunnybrook Health Sciences Center. Demographic information, clinical data, tumor stage, treatment and follow up were reviewed. Patients with colorectal well-differentiated neuroendocrine tumors (carcinoid tumor), large cell neuroendocrine carcinoma, poorly differentiated carcinoma 
with focal neuroendocrine differentiation or with history of Merkel cell tumors of the skin, primary SmCC of the lung or other organs were excluded. All patients included in this study had either chest plain radiograph or a chest CT that was free of tumor.

H\&E-stained sections were reviewed by two pathologists to confirm the diagnosis. The histological criteria applied for the diagnosis were the same as those used for the diagnosis of pulmonary SmCC. These criteria required that the entire tumor in the submitted material consists of cohesive round to oval cells with sparse cytoplasm, nuclei with salt and pepper chromatin, nuclear moulding and small or inconspicuous nucleoli. These features needed to be present in the setting of brisk mitoses, apoptosis and necrosis (Figure 1). As per the local surgical pathology protocols, submitted representative tissue sections were routinely processed and embedded in paraffin. Sections $(2-3 \mu \mathrm{m})$ of the tumor, through its most invasive part and including adjacent normal mucosa when possible, were stained for immunohistochemistry using standard avidinbiotin complex method. The panel of antibodies used summarized in Table 1. Results of immunostains were assessed by two pathologists and a consensus regarding controversial cases was reached at the double-headed microscope. Evaluation of the immunohistochemical staining was performed by light microscopy using a $10 \times$ eye-piece lense with the selective use of $20-40 \times$ objective lense for confirmation. The markers were evaluated by a semiquantitative method. With the exception of CDX2 and TTF-1 which showed nuclear staining, and EGFR

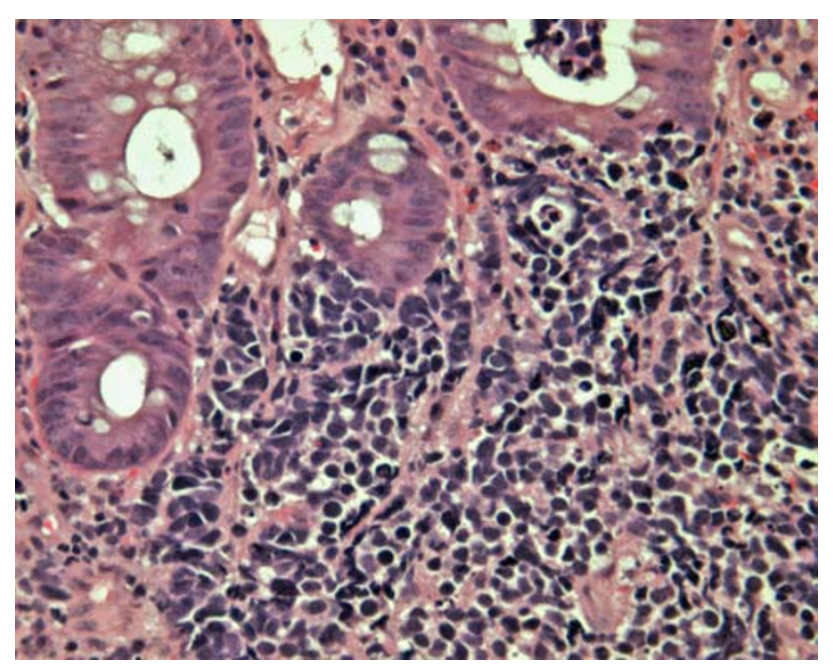

Figure I

A colonic small cell carcinoma with brisk mitoses, apoptosis and necrosis. Adjacent colonic mucosal crypts are non-dysplastic. $(H \& E \times 400)$. which showed cell membrane staining, cytoplasmic staining was required for all other immunostains.

\section{Results}

Ten patients with primary CRSmCC were identified with their demographic and clinical findings summarized in Table 2. Their age ranged from $39-88$ (median $=60$ ). There were 7 females and 3 males. Family history of colorectal cancer was present in one patient and 2 had a history of inflammatory bowel disease. Three patients had synchronous adenomas in the large bowel. Nine cases presented with symptoms related to a colorectal mass and/or metastasis while one case presented with biliary colic. Seven cases had tumors arising in the rectum including the anorectal junction. Nine of the ten patients had distant metastases at the time of diagnosis. The commonest metastatic site was the liver present in 6 cases.

On routine $\mathrm{H} \& \mathrm{E}$ sections, all our cases showed solid nests and clusters of small to medium sized cells, displaying prominent apoptosis, nuclear moulding, brisk mitosis (>10/10 HPFs) and necrotic foci. Their nuclei showed classic salt and pepper chromatin with indistinct nucleoli. Occasional rosette formation was noted. Two of the cases were associated with other colonic pathology; one of which showed a colonic adenoma away from the SmCC while the other showed colonic adenocarcinoma arising from tubulovillous adenomas, merging with the lateral edge of the SmCC. In all the cases, there was no evidence of divergent differentiation in tehe form of squamous, acinar (glandular) or large cell neuroendocrine. Lymphovascular invasion was present in all of our cases. None of the cases showed Azzopardi effect, however crushing artefacts were noted in all the cases.

Our immunohistochemical panel showed that all cases were positive for low molecular weight cytokeratin (LMWK), CK 19 and pancytokeratin but were negative for TTF-1 and CA 125. CK 7 expression was variable but that of CK 20 was restricted to tumors of the right colon. Immunostaining for neuroendocrine differentiation including CD56, synaptophysin, NSE, and chromogranin was variable but every case showed positivity with at least one of these markers (Figures 2 and 3). CDX2 was positive in only 2 cases while mCEA was positive in 2 cases. EGFR was positive in 7 cases (Figure 4). Results of the immunohistochemistry are summarized in Table 3 . The case with the associating adenocarcinoma component showed similar immunohistochemical profile (including EGFR expression) in both tumors, except for the lack of CD56, synaptophysin and chromogranin expressions and the presence of CEA expression in the adenocarcinoma. 
Table I: The panel of immunohistochemical reagents used

\begin{tabular}{|c|c|c|c|c|}
\hline Antibody & Clone & Manufacturer & Pre-treatment & $\begin{array}{l}\text { Diluti } \\
\text { on }\end{array}$ \\
\hline CK 7 & $\begin{array}{l}\text { OV-TL I2/ } \\
30\end{array}$ & Dako (Carpinteria, CA) & Pepsin for 10 minutes at $37^{\circ} \mathrm{C}$ & $1 / 4000$ \\
\hline CK 20 & KS 20.8 & Novocastra (Vision Biosystem, Norwell, MA) & Pepsin for 10 minutes at $37^{\circ} \mathrm{C}$ & $1 / 50$ \\
\hline Synaptophysin & $27 G \mid 2$ & Vector (Burlingame, CA) & HIER at $\mathrm{pH} 6.0$ & $1 / 200$ \\
\hline Chromogranin A & Polyclonal & Dako (Carpinteria, CA) & Pepsin for 10 minutes at $37^{\circ} \mathrm{C}$ & $1 / 200$ \\
\hline CD56 & $123 \mathrm{C} 3$ & Zymed (Invitrogen, Carlsbad, CA) & HIER at $\mathrm{pH} 6.0$ & $1 / 200$ \\
\hline NSE & Polyclonal & Dako (Carpinteria, CA) & None & $1 / 250$ \\
\hline EGFR & 3 IG7 & Zymed (Invitrogen, Carlsbad, CA) & Pepsin for 10 minutes at $37^{\circ} \mathrm{C}$ & $1 / 100$ \\
\hline LMWK & Cam 5.2 & B.D. Bioscience (San Jose, CA) & Pepsin for 10 minutes at $37^{\circ} \mathrm{C}$ & $1 / 64$ \\
\hline CK 19 & 6170 & Novocastra (Vision Biosystem, Norwell, MA) & Pepsin for 10 minutes at $37^{\circ} \mathrm{C}$ & $1 / 50$ \\
\hline Pankeratin & AEI/AE3 & Dako (Carpinteria, CA) & Pepsin for 10 minutes at $37^{\circ} \mathrm{C}$ & $1 / 300$ \\
\hline TTF-I & $8 G 7 G 3 / 1$ & Neomarker (Lab Vision, Fremont, CA) & HIER at $\mathrm{pH} 6.0$ & $1 / 800$ \\
\hline CA 125 & Ov185:I & Novocastra (Vision Biosystem, Norwell, MA) & HIER at $\mathrm{pH} 6.0$ & $1: 100$ \\
\hline $\mathrm{CD} \times 2$ & Amt 28 & Vision Biosystem (Norwell, MA) & HIER at $\mathrm{pH} 8.0$ & $1 / 50$ \\
\hline mCEA & B80-I & Biomeda (Foster City, CA) & None & $1 / 200$ \\
\hline
\end{tabular}

HIER = Heat-induced epitope retrieval, in a Biocare decloaking chamber

The standard management for CRSmCC during this period of review was combined chemotherapy and radiotherapy similar to protocols used in SmCC of the lung.

Five patients received VP16 and cis-platinum with or without consolidation therapy to the local disease. However, two patients deteriorated rapidly and died of metastatic disease prior to the initiation of systemic chemotherapy. Four cases were treated by surgery ( 2 with right hemicolectomy, 1 with low anterior resection and 1 with abdomino-perineal resection) with or without postoperative adjuvant chemotherapy.

The median follow up was 3 years (10 months - 4 years), during which 7 patients died of disease. The remaining 3 cases were alive with disease at last follow-up.

\section{Discussion}

Primary extra-pulmonary SmCC is uncommon, occurring in only $4 \%$ of all patients with SmCC [2]. While its actual incidence may be underestimated, SmCC presents $0.1 \%$ to $1 \%$ of all gastrointestinal (GI) malignancies, with varying incidence in different organs [3]. SmCC is estimated to represent $1 \%$ to $2.8 \%$ of all esophageal cancer, with the esophagus being the commonest site for GI SmCC [4-9]. The second most common location is the colorectum where SmCC accounts for $0.2 \%-0.8 \%$ of all colorectal neoplasms [10-12]. Primary SmCC has been described in most organs of the body [3,13-20], except the central nervous system. 12 The majority of patients with GI SmCC present with overt distant metastases [3]. In our study, the commonest symptom was abdominal pain and 9 of our 10 cases had metastatic disease at the time of diagnosis. The commonest primary site is the rectum, followed by the cecum and sigmoid colon [3]. Similarly, in our series, the tumor occurred in the rectum including the anorectal junction in 7 patients. In one series, a predominance of the disease in older men (mean age $=64$ years) was reported [3]. Our patients ranged in age from 39-88 years old with a median age of 60 years and showed a female predominance with a female to male ratio of $2: 1$. Three of our 10 cases had adenomas in the vicinity of their tumors and 2 had inflammatory bowel disease but none was immunodeficient. The association of CRSmCC with inflammatory bowel disease and adenoma either within or away from the SmCC has been documented earlier $[10,21]$, however their possible role in CRSmCC carcinogenesis remains uncertain.

The role of immunohistochemistry in establishing the diagnosis of CRSmCC has been a subject of considerable debate. To some authors, the classic histological features on H\&E-stained sections are sufficient for the diagnosis [22]. However, for many others, the documentation of neuroendocrine differentiation is essential to compliment the characteristic morphologic features [23]. SmCC usually shows positive staining for chromogranin and synaptophysin with strong and diffuse immunoreactivity for CD56 [22,24]. In our series, CD56 was more sensitive than chromogranin and synaptophysin as it was positive in 9 of the 10 cases. In the current study, we excluded other neuroendocrine tumors as carcinoid, atypical carcinoid and large cell neuroendocrine carcinomas based on tumor morphology in order to limit our immunohistochemical assessment to pure small cell carcinomas.

Pancytokeratin (AE1/AE3) and LMWK (Cam5.2) are reported to be positive in all SmCC [22]. Similar findings were present in our cases and in addition, CK 7 and 19 expression was also noted in all cases. We also report the 


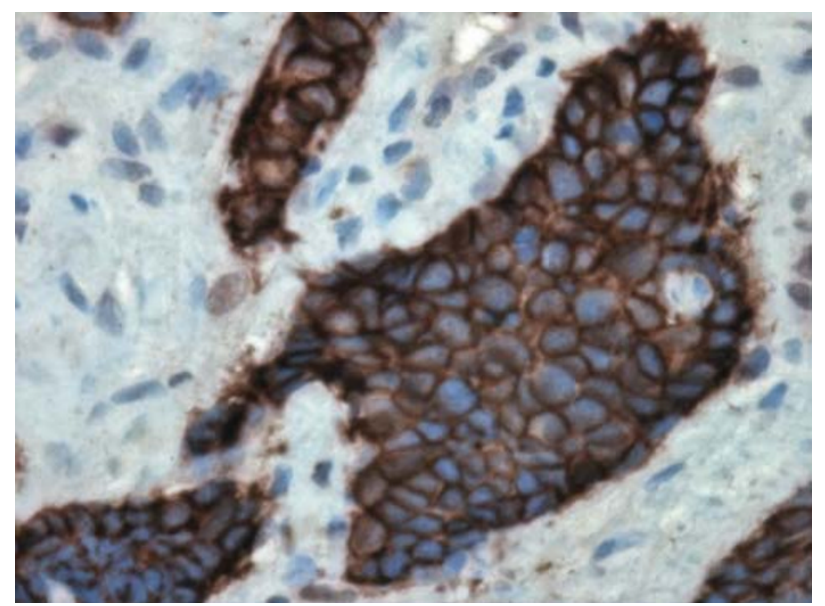

Figure 2

A small cell carcinoma of the ascending colon with immunopositivity to CD56. (CD56 × 400).

patterns of staining for cytokeratins 7 and 20 staining with CK 7+/CK 20- in 4 cases, CK 7-/CK 20+ in 2 cases, and CK 7 -/CK 20- in 4 cases. Our series is the first to document the limitation of CK 20 immunohistochemistry in CRSmCC. None of the rectal SmCC was positive for CK 20. CK 19 was positive in all 10 cases studied. Since its expression is also noted in conventional colorectal adenocarcinoma, CK 19 has a limited value in distinguishing it from CRSmCC [25]. To the best of our knowledge, there are no previous reports in the English literature describing the expression of cytokeratins 7, 19, and 20 in CRSmCC.

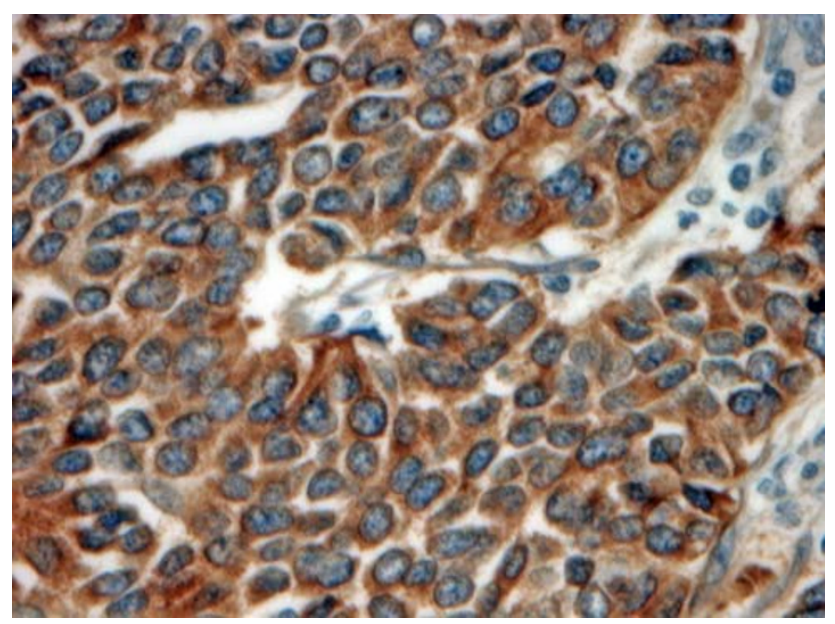

\section{Figure 3}

A rectal small cell carcinoma showing positive synaptophysin immunostaining. (Synaptophysin $\times 400$ ).

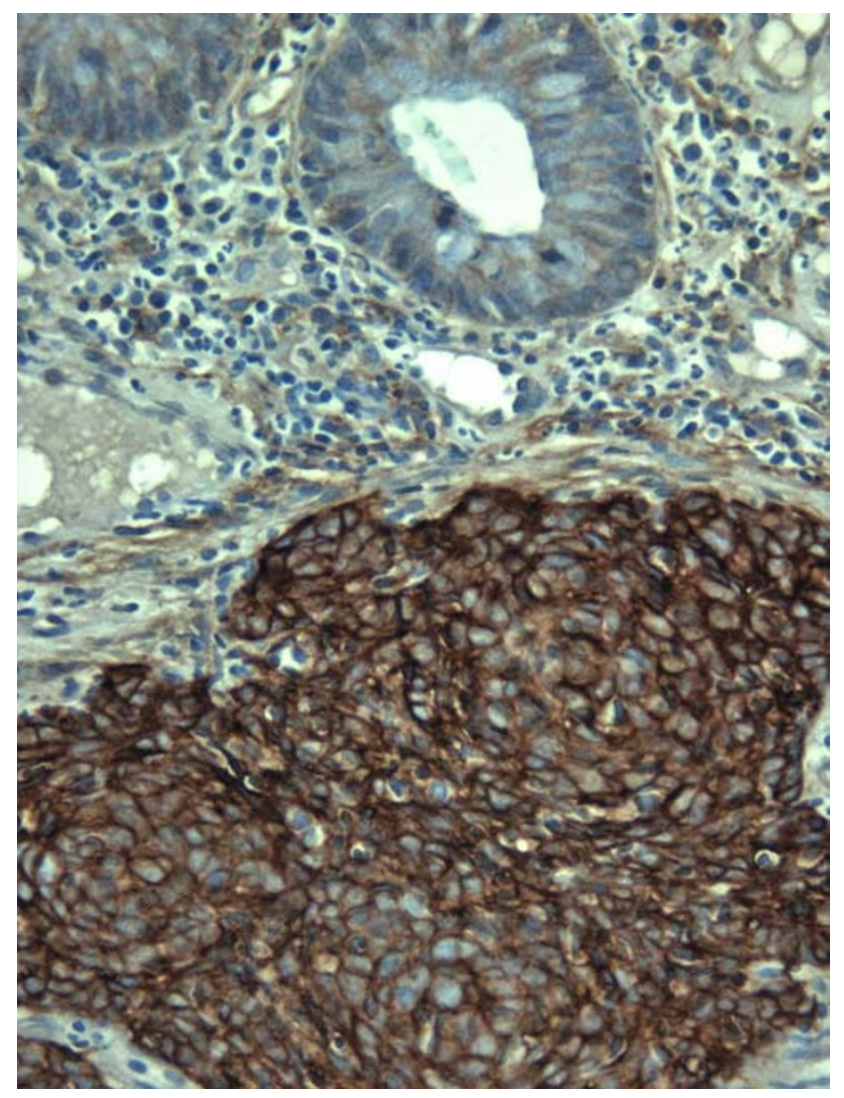

\section{Figure 4}

A rectal small cell carcinoma showing positive EGFR immunostaining. $(E G F R \times 400)$.

Thyroid transcription factor-1 (TTF-1) is a nuclear homeodomain transcription factor that is expressed in the developing thyroid, respiratory epithelium, and diencephalon [26]. Several studies have documented that TTF1 could not be used in distinguishing pulmonary from extra-pulmonary SmCC due to the extensive overlap in these tumors' immunophenotypes. With the exception of cases with skin tumors, TTF-1 could not be reliably used to distinguish primary from metastatic SmCC in extrapulmonary sites [26-28]. In one study, TTF-1 was reported to be positive in the vast majority of pulmonary $(81 \%)$ and extra-pulmonary (80\%) SmCC with the exception of Merkel cell tumor [28]. Another study reported that TTF-1 was expressed in $82.7 \%$ of pulmonary SmCCs, $42.0 \%$ of extra-pulmonary SmCCs (range, 33.3 - 53.3\% for the various sites), and $0 \%$ of Merkel cell carcinomas [26]. Interestingly, none of these extra-pulmonary SmCC cases included in both studies involved the colorectum $[26,28]$. With relatively limited data, staining for TTF- 1 seems to be uniformly negative in CRSmCC.[29] The results of our study support this observation highlighting the value of TTF-1 immunostaining in differentiating SmCC of a 
Table 2: Demographic and clinical summary

\begin{tabular}{|c|c|c|c|c|c|c|c|c|}
\hline Case & Age/Sex & Site & History & Present-Ation & Metastasis/Site & Procedure & $\begin{array}{l}\text { Associated } \\
\text { Pathology }\end{array}$ & Follow up \\
\hline 1 & $65 / M$ & Ileocecal & ? Cholecystitis & Abdom-inal Pain & - & $\begin{array}{l}\text { Right } \\
\text { Hemicolectomy } \\
\text { (pT3 N2) }\end{array}$ & $\begin{array}{l}\text { Tubulovillous } \\
\text { adenoma with } \\
\text { invasive } \\
\text { adenocarcinoma } \\
\text { adjacent to } \\
\text { SmCC }\end{array}$ & DOD \\
\hline 2 & $69 / M$ & $\begin{array}{l}\text { Ascending } \\
\text { colon }\end{array}$ & $\begin{array}{l}\text { Family history of } \\
\text { colon cancer }\end{array}$ & Abdominal pain & +/Liver & $\begin{array}{l}\text { Biopsy + Right } \\
\text { Hemicolectomy } \\
\text { (pT2 N2) }\end{array}$ & Adenoma & DOD \\
\hline 3 & $88 / F$ & $\begin{array}{l}\text { Ascending } \\
\text { colon }\end{array}$ & $\begin{array}{l}\text { Mass adjacent to } \\
\text { colon }\end{array}$ & Pleural Effusion & $\begin{array}{l}\text { +/Medias-tinal } \\
\text { lymph nodes and } \\
\text { liver }\end{array}$ & Biopsy & - & DOD \\
\hline 4 & $42 / F$ & Rectum & $\begin{array}{l}2 \text { previous } \\
\text { negative rectal } \\
\text { biopsies a year } \\
\text { earlier }\end{array}$ & Abdominal pain & +/Liver & Biopsy & - & AWD \\
\hline 5 & $43 / F$ & Rectum & Ulcerative colitis & $\begin{array}{l}\text { Abdominal Pain } \\
\text { and weight loss }\end{array}$ & $\begin{array}{l}\text { +/Retro- } \\
\text { peritoneal, } \\
\text { inguinal lymph } \\
\text { nodes, liver and } \\
\text { skin }\end{array}$ & Biopsy & Ulcerative colitis & DOD \\
\hline 6 & $49 / F$ & Rectum & $\begin{array}{l}\text { Rectal villous } \\
\text { adenoma } 2 \text { years } \\
\text { earlier }\end{array}$ & Abdominal Pain & $\begin{array}{l}\text { +/Para-aortic } \\
\text { lymph nodes and } \\
\text { liver }\end{array}$ & Biopsy & - & DOD \\
\hline 7 & $59 / F$ & Rectum & Crohn's disease & Abdominal pain & $\begin{array}{l}\text { +/Para-aortic } \\
\text { lymph nodes }\end{array}$ & $\begin{array}{l}\text { Biopsy + Low } \\
\text { anterior resection } \\
\text { (pT3 N2) }\end{array}$ & $\begin{array}{l}\text { Crohn's disease } \\
+3 \text { tubular } \\
\text { adenomas away } \\
\text { from SmCC }\end{array}$ & DOD \\
\hline 8 & $66 / F$ & Rectum & - & $\begin{array}{l}\text { Stool } \\
\text { incontinence }+ \\
\text { Rectal pain }\end{array}$ & $\begin{array}{l}\text { +/Groin lymph } \\
\text { nodes }\end{array}$ & Biopsy & - & AWD \\
\hline 9 & $39 / M$ & Rectum & - & Rectal urgency & $\begin{array}{l}\text { +/Exten-sion to } \\
\text { pelvic side walls }\end{array}$ & $\begin{array}{l}\text { Biopsy, loop } \\
\text { colostomy, then } \\
\text { abdomino- } \\
\text { perineal resection }\end{array}$ & SIADH & DOD \\
\hline 10 & $61 / F$ & $\begin{array}{l}\text { Ano-rectal } \\
\text { junction }\end{array}$ & - & Rectal bleeding & +/Liver & Biopsy & - & AWD \\
\hline
\end{tabular}

AWD $=$ Alive with disease. $D O D=$ Dead of disease

colorectal from that of a pulmonary origin. This is particularly significant in CRSmCC with lung metastases to exclude primary lung tumors or in patients with synchronous malignancies. However the presence of CK $20+/ \mathrm{TTF}-$ 1 - subset of CRSmCC highlights the morphological and immunohistochemical overlap between CRSmCC and Merkel cell carcinoma. CDX2 and mCEA are rarely expressed in CRSmCC and hence they may be of value in differentiating it from poorly differentiated colorectal adenocarcinoma. To the best of our knowledge, no previous study has described CDX2 expression in CRSmCC. The diagnostic value of CDX2 in Merkel cell tumor has not yet been established.

Seven of our cases showed EGFR expression. Reporting EGFR immunostaining in conventional primary colorec- tal adenocarcinoma and its metastasis has extensively been studied recently $[30,31]$. The current study is the first to report EGFR expression in CRSmCC which could have management and prognostic implications through the possible use of targeted biological therapy in these tumors, if similar results are shown in larger series.

Similar to SmCC of the lung, CRSmCC usually presents with distant metastases [32-34]. Nine of our 10 patients had metastases at the time of diagnosis. The prognosis of CRSmCC is worse than that of stage-matched conventional colorectal adenocarcinomas [22]. With the exception of Merkel cell tumor, the standard management for SmCC has increasingly become systemic chemotherapy [35] whether the tumor is pulmonary or extrapulmonary. In spite of the initial response to chemotherapy, radio- 
Table 3: Summary of immunohistochemical staining

\begin{tabular}{|c|c|c|c|c|c|c|c|c|c|c|c|c|c|c|}
\hline Case & CK 7 & CK 20 & Synp & Chrom & CD 56 & NSE & EGFR & LMWK & CK 19 & $\begin{array}{l}\mathrm{AEI} / \\
\mathrm{AE3}\end{array}$ & TTF-I & $\begin{array}{l}\text { CA } \\
125\end{array}$ & CDX 2 & mCEA \\
\hline I & - & + & + & + & + & + & + & + & + & + & - & - & - & - \\
\hline 2 & - & + & + & - & + & + & - & + & + & + & - & - & - & + \\
\hline 3 & + & - & - & - & + & - & + & + & + & + & - & - & - & - \\
\hline 4 & - & - & + & - & + & + & - & + & + & + & - & - & - & - \\
\hline 5 & + & - & - & - & + & - & + & + & + & + & - & - & - & + \\
\hline 6 & + & - & - & + & - & + & + & + & + & + & - & - & - & - \\
\hline 7 & - & - & + & + & + & - & + & + & + & + & - & - & - & - \\
\hline 8 & - & - & + & + & + & + & - & + & + & + & - & - & - & - \\
\hline 9 & + & - & + & + & + & + & + & + & + & + & - & - & + & - \\
\hline 10 & - & - & + & + & + & + & + & + & + & + & - & - & + & - \\
\hline
\end{tabular}

Synp $=$ Synaptophysin

Chrom = Chromogranin

therapy and possibly surgery depending on the extent of residual disease or response $[12,16]$, patients invariably relapse and die rapidly of distant metastases.

\section{Conclusion}

SmCC is an aggressive tumor of the large bowel with a predilection for the rectum. This study reports for the first time the various CK7/CK20 immunostaining patterns encountered, its predominant negative staining with CDX2 and the expression of EGFR in more than half of these tumors. It elaborates on the practical use of immunohistochemistry in the differential diagnosis.

\section{Acknowledgements}

This work was presented in part at the United States and Canadian Academy of Pathology Annual Meeting, San Diego, CA, March 2007.

\section{References}

I. Bernick PE, Klimstra DS, Shia J, Minsky B, Saltz L, Shi W, Thaler H, Guillem J, Paty P, Cohen AM, Wong WD: Neuroendocrine carcinomas of the colon and rectum. Dis Colon Rectum 2004, 47:163-169.

2. Levenson RM, Ihde DC, Matthews MJ, Cohen MH, Gazdar AF, Bunn PA, Minna JD: Small cell carcinoma presenting as an extrapulmonary neoplasm: Sites of origin and response to chemotherapy. J Natl Cancer Inst 198I, 67:607-6I2.

3. Brenner B, Tang LH, Klimstra DS, Keslen DP: Small-Cell Carcinomas of the Gastrointestinal Tract: A Review. J Clin Oncol 2004, 22(13):2730-2739.

4. Medgyesy CD, Wolff RA, Putnam JB, Arjani JA: Small cell carcinoma of the esophagus: The University of Texas $M$. D. Anderson Cancer Center experience and literature review. Cancer 2000, 88:262-267.

5. Bennouna J, Bardet E, Deguiral P, Douillard JY: Small cell carcinoma of the esophagus: Analysis of 10 cases and review of the published data. Am J Clin Oncol 2000, 23:455-459.

6. Chow V, Law S, Lam KY, Luk JM, Wong J: Telomerase activity in small cell esophageal carcinoma. Dis Esophagus 200I, 14:139-142.

7. Mitani M, Kuwabara Y, Shinoda N, Sato A, Fujii Y: Long-term survivors after the resection of limited esophageal small cell carcinoma. Dis Esophagus 2000, 13(3):259-261.

8. Lam KY, Law S, Tung PH, Wong J: Esophageal small cell carcinomas: Clinicopathologic parameters, p53 over expression, proliferation marker, and their impact on pathogenesis. Arch Pathol Lab Med 2000, I 24(2):228-233.
9. Craig SR, Carey FA, Walker WS, Cameron EW: Primary small-cell cancer of the esophagus. J Thorac Cardiovasc Surg 1995, 109:284-288.

10. Yaziji H, Broghamer WJ: Primary small cell undifferentiated carcinoma of the rectum associated with ulcerative colitis. South Med J 1996, 89:92I-924.

II. Kim JH, Lee SH, Park J, Kim HY, Lee SI, Nam EM, Park JO, Kim K, Jung CW, Im YH, Kang WK, Lee MH, Park K: Extrapulmonary Smallcell Carcinoma: a Single institution Experience. Jpn J Clin Oncol 2004, 34(5):250-254.

12. Remick SC, Ruckdeschel JC: Extrapulmonary and pulmonary small-cell carcinoma: tumor biology, therapy, and outcome. Med Pediatr Oncol 1992, 20(2):89-99.

13. Chaudhary UB, Taksey JD, Johnson RD, Lewin DN: Small cell carcinoma of the stomach. Journal of Clinical Oncology 2003, 2I(I 2):244I-2442.

14. Noguchi T, Takeno S, Kato T, Wada S, Noguchi T, Uchida Y, Kashima K, Yokoyama S: Small cell carcinoma of the esophagus; clinicopathological and immunohistochemical analysis of six cases. Dis Esophagus 2003, 16:252-258.

15. Kuwabara $\mathrm{H}$, Uda $\mathrm{H}$ : Small cell carcinoma of the gall-bladder with intestinal metaplastic epithelium. Pathol Int 1998, 48(4):303-306.

16. Majhail NS, Elson P, Bukowski RM: Therapy and outcome of small cell carcinoma of the kidney: report of two cases and a systemic review of the literature. Cancer 2003, 97: I436-I44I.

17. Sykes AJ, Shanks JH, Davidson SE: Small cell carcinoma of the uterine cervix: a clinicopathological review. Int J Oncol 1999, 14:38I-386

18. Sengoz M, Abacioglu U, Salepci T, Eren F, Yumuk F, Turhal S: Extrapulmonary small cell carcinoma: multimodality treatment results. Tumori 2003, 89:274-277.

19. Remick SC, Hafez GR, Carbone PP: Extrapulmonary small-cell carcinoma. A review of the literature with emphasis on therapy and outcome. Medicine (Baltimore) 1987, 66(6):457-47I.

20. Shamelian SO, Nortier JW: Extrapulmonary small cell carcinoma: report of three cases and update of therapy and prognosis. Neth J Med 2000, 56:5I-55.

21. Casas F, Ferrer F, Farrus B, Casals J, Biete A: Primary small cell carcinoma of the esophagus: A review of the literature with emphasis on therapy and prognosis. Cancer 1997, 80: $1366-1372$.

22. Gaffey MJ, Mills SE, Lack EE: Neuroendocrine carcinoma of the colon and rectum: A clinicopathologic, ultrastructural, and immunohistochemical study of $\mathbf{2 4}$ cases. Am J Surg Pathol 1990, 14:1010-1023.

23. Demellawy DE, Samkari A, Sur M, Denardi F, Alowami S: Primary small cell carcinoma of the cecum. Ann Diag Pathol 2006, 10(30): 162-165.

24. Kaufmann O, Georgi T, Deitel M: Utility of I23 C3 monoclonal antibody against CD56 (NCAM) for the diagnosis of small cell carcinoma on paraffin sections. Hum Pathol 1997, 28(12): $1373-1378$. 
25. Lau SK, Prakash S, Geller SA, Alsabeh R: Comparative immunohistochemical profile of hepatocellular carcinoma, cholangiocarcinoma, and metastatic adenocarcinoma. Hum Pathol 2002, 33(I 2): ||75-||8|.

26. Agoff SN, Lamps LW, Philip AT, Amin MB, Schmidt RA, True LD, Folpe AL: Thyroid transcription factor- $I$ is expressed in extrapulmonary small cell carcinomas but not in other extrapulmonary neuroendocrine. Modern Pathology 2000, I3(3):238-242.

27. Cheuk W, Kwan MY, Suster S, Chan JK: Immunostaining for thyroid transcription factor $I$ and cytokeratin 20 aids the distinction of small cell carcinoma from Merkel cell carcinoma, but not pulmonary from extrapulmonary small cell carcinomas. Arch Pathol Lab Med 200I, I 25(2):228-23I.

28. Kaufmann O, Deitel M: Expression of thyroid transcription factor- $I$ in pulmonary and extrapulmonary small cell carcinomas and other neuroendocrine carcinomas of various primary sites. Histopathology 2000, 36(5):4I5-420.

29. Ordonez NG: Value of thyroid transcription factor-I immunostaining in distinguishing small cell lung carcinomas from other small cell carcinomas. Am J Surg Pathol 2000, 24:1217-1223.

30. Khalifa MA, Rowsell CH, Gladdy RA, Ko YJ, Hanna S, Smith A, Law C: Expression of epidermal growth factor receptor (EGFR) in primary colorectal adenocarcinoma predicts its expression in recurrent disease. Am J Clin Pathol 2006, I 25: I-5.

31. Khalifa MA, Rowsell CH, Gladdy R, Ko YJ, Hanna S, Smith A, Law C: Is EGFR expression altered following postoperative chemotherapy for colorectal adenocarcinoma? World J Surg Oncol 2006, I 24:92.

32. Mills SE, Allen MS Jr, Cohen AR: Small-cell undifferentiated carcinoma of the colon: A clinicopathological study of five cases and their association with colonic adenomas. Am J Surg Pathol 1983, 7:643-65।.

33. Wick MR, Weatherby RP, Weilland LH: Small cell neuroendocrine carcinoma of the colon and rectum: clinical, histologic, and ultrastructural study and immunohistochemical comparison with cloacogenic carcinoma. Hum Pathol 1987, I8(I):9-2I.

34. Schwartz AM, Orenstein JM: Small-cell undifferentiated carcinoma of the rectosigmoid colon. Arch Pathol Lab Med 1985, 109(7):629-632.

35. Brenner B, Shah MA, Gonen M, Klimstra DS, Shia J, Kelsen DP. Small-cell carcinoma of the gastrointestinal tract: a retrospective study of 64 cases. Br J Cancer 2004, 90(9): 1720-1726.

Publish with Bio Med Central and every scientist can read your work free of charge

"BioMed Central will be the most significant development for disseminating the results of biomedical research in our lifetime. "

Sir Paul Nurse, Cancer Research UK

Your research papers will be:

- available free of charge to the entire biomedical community

- peer reviewed and published immediately upon acceptance

- cited in PubMed and archived on PubMed Central

- yours - you keep the copyright
BioMedcentral 